\title{
Phytochemical characterization and Antibacterial potentials of Mangifera indica L. bark oil
}

\author{
Chetan B. Savant ${ }^{1 *}$, Anandrao R. Kulkarni ${ }^{1}$, Basel A. Abdel-Wahab ${ }^{2,3}$, Awad Mohammed Al-Qahtani ${ }^{3}$, \\ Basheerahmed Abdulaziz Mannasaheb ${ }^{4}$, Ibrahim A. Shaikh ${ }^{5}$ \\ ${ }^{1}$ Department of Pharmacology, Soniya College of Pharmacy, Dharwad, Karnataka, 580002, India. \\ ${ }^{2}$ Department of Pharmacology, College of Medicine, Assiut University, Assiut, Egypt. \\ ${ }^{3}$ Department of Family Medicine, Faculty of Medicine, Najran University, Najran, Saudi Arabia \\ ${ }^{4}$ Department of Pharmacology, Al-Maarefa Colleges for Science and Technology, Riyadh, Saudi Arabia. \\ ${ }^{5}$ Department of Pharmacology, College of Pharmacy, Najran University, Najran, Saudi Arabia.
}

\begin{tabular}{|c|c|}
\hline ARTICLE INFO & ABSTRACT \\
\hline Article history: & \multirow{9}{*}{$\begin{array}{l}\text { There has been a ruthless increase in antimicrobial resistance in most of the pathogenic microorganisms all over } \\
\text { the world due to irrational use of antimicrobial agents. Although number of novel antimicrobial drugs are being } \\
\text { brought to the market has shown steady decline in the past decades. This gives widespread opportunities to } \\
\text { researchers for the discovery of new antimicrobial agent. Objective of the study was to evaluate antimicrobial } \\
\text { activity of petroleum ether extract of Mangifera indica Linn. bark by disk diffusion and broth microdilution } \\
\text { method to determine inhibition zone diameters and minimum inhibitory concentration (MIC). The organisms } \\
\text { exhibited different degree of susceptibility to the inhibitory activity of the crude extract. Amongst the selected } \\
\text { pathogenic bacteria P. Aeruginosa has shown maximum zone of inhibition of } 20 \mathrm{~mm} \text { at } 75 \mu 1 \text { of extract. } \\
\text { Whereas } E \text {. coli, S. aureus, and } B \text {. subtilis has MIC of } 0.2 \mu \mathrm{g} / \mathrm{ml} \text {. Extract consists of various volatile oil, fatty } \\
\text { acids, which has significant lipophilicity this may contribute to the inhibition microbial growth. }\end{array}$} \\
\hline Received on: 01/10/2016 & \\
\hline Accepted on: 02/01/2017 & \\
\hline Available online: $30 / 04 / 2017$ & \\
\hline Key words: & \\
\hline Mangifera indica Linn., & \\
\hline antimicrobial activity; & \\
\hline minimum inhibitory & \\
\hline $\begin{array}{l}\text { concentration; zone of } \\
\text { inhibition. }\end{array}$ & \\
\hline
\end{tabular}

\section{INTRODUCTION}

In the developing countries, infectious diseases account for high proportion of health problems. Resistance to antimicrobial drugs has become an increasingly important and pressing global problem. Of the 2 million people who acquire bacterial infections in US hospitals each year, $70 \%$ of cases involve strains that are resistant to at least one drug (Tim-cushnie et al., 2005). This situation forced researchers to discover new antimicrobial substances from various sources, such as medicinal plants (Karaman et al., 2003). Plants as a source of remedies are widely used for the treatment of almost $87 \%$ human alignments

\footnotetext{
* Corresponding Author

Chetan B Savant, Department of Pharmacology, Soniya College of Pharmacy, Dharwad, Karnataka, 580002, India.

Email: chetan.savant @yahoo.com
}

including fungal, bacterial infections, cancer and different disorders (Abu Mustafa et al., 1961). Mangifera indica L. (family: Anarcardiaceae) is the most economically and culturally important tropical rainforest medicinal plant in Asia and Africa, especially for its edible fruits. The mango tree is an erect perennial tree with a broad rounded canopy which at full maturity may attain up to 10$30 \mathrm{~m}$ and 30-35 $\mathrm{m}$ in height and width (Shah et al., 2010). Previous studies indicate mango possesses antidiabetic, hypolipidemic, antioxidant, antiviral, cardiotonic, hypotensive, antipyretic and analgesic, anti bone resorption, antihelminthic, antispasmodic, anti-inflammatory, antidiarrheal, antiallergic, gastroprotective, hepatoprotective and immunomodulatory properties (Adeneye et al., 2015). Oil of mango tree bark is an effective home remedy for a sore throat and can be used to cure throat infections (Chetan et al., 2014). 
In the present study, we have isolated a fatty fraction of Mangifera indica Linn. bark using petroleum ether and subjected to Gas chromatography-Mass spectroscopy (GC-MS) and physical characterization. The extract was also screened for its antimicrobial activity using Gram positive ( $S$. aureus and B. subtilis) and Gram negative (E. coli and P. aeruginosa) bacteria.

\section{MATERIALS AND METHODS}

\section{Plant material}

Mangifera indica stem barks were collected from the Nigadi region of Dharwad (Karnataka, India) in the month of August 2011. The plant was authenticated by Dr. G. R. Hegde (Voucher specimen number- PB/GRH/KUD-563 deposited in museum Karnataka university, Dharwad-580003). The stem barks were inspected to be healthy, collected and were washed with water thrice in the bucket and dried overnight over a cotton cloth.

\section{Preparation of the extract}

The stem barks were grounded to a fine powder using a domestic electric grinder. Powdered stem barks were passed through the sieve no.20. Around $100 \mathrm{~g}$ of powder was collected and extracted with Petroleum ether $60^{\circ}-80^{\circ}$ ( $8 \times 300 \mathrm{ml} ; 8 \mathrm{hrs}$ each) using soxhlet apparatus. Finally, the fatty residue was collected and evaporated to dryness. Spectral characterization of the extract was carried out with the help of TLC and GC-MS.

\section{Thin layer chromatography (TLC)}

TLC plate was prepared by using silica gel (GF 254), air dried and kept for activation at $110^{\circ} \mathrm{C}$ for $30 \mathrm{~min}$. n-hexane and ethyl acetate were used as mobile phase in ratio of 9:1. TLC chamber was kept for saturation. MIE (Mangifera indica extract) was dissolved in chloroform and sample spot was put $1 \mathrm{~cm}$ from the end of the plate. The plate was further placed in chamber for development. After development, the plate was air dried and kept in iodine chamber for spot visualization. The $R_{f}$ value was calculated.

\section{Gas chromatography - mass spectroscopy (GCMS)}

The isolated MIE was dissolved in Dimethyl sulfoxide and subjected to GCMS (Shimadzu).

\section{In-vitro antimicrobial activity}

The following microorganisms were used for testing antibacterial activity. Gram-positive bacteria: Staphylococcus aureus ATCC 12598, Bacillus subtilis ATCC 6633. Gramnegative bacteria: Escherichia coli ATCC 25922, Pseudomonas ATCC 25619

\section{Determination of minimum inhibitory concentration (MIC)}

Nine dilutions of each test samples were made with brain heart infusion broth (BHI) for MIC. $10 \mathrm{mg}$ of compound (MIE) was dissolved in $1 \mathrm{ml}$ of DMSO i.e solvent. Then 10 test tubes were arranged serially. In first test tube $300 \mu \mathrm{l}$ of BHI was added and from $2^{\text {nd }}$ to $10^{\text {th }}$ tube $200 \mu \mathrm{l}$ of BHI was added. After that 100 $\mu l$ of the drug was added to the $1^{\text {st }}$ tube (master dilution). Then 200 $\mu \mathrm{l}$ of master dilution was transferred to $2^{\text {nd }}$ tube and likewise we did till $10^{\text {th }}$ tube. $200 \mu \mathrm{l}$ was discarded from the $10^{\text {th }}$ tube. Then $200 \mu \mathrm{l}$ of the organism was added from $1^{\text {st }}$ tube to last tube and incubated the tubes in an incubator for $24 \mathrm{hrs}$ at $37^{\circ} \mathrm{C}$. After $24 \mathrm{hrs}$ tubes were observed for turbidity (Schwalve et al., 2007).

\section{Determination of zone of inhibition}

Sterile BHI agar media was used to carry out Disc Diffusion Assay. The agar plates were brought to room temperature prior to use. Selected bacterial colonies were transferred to the plates with help of a loop. Turbidity was adjusted, equal to that of a $0.5 \mathrm{McF}$ arland turbidity standard with broth and standardized the suspension with a photometric device. A hollow tube of $5 \mathrm{~mm}$ diameter was heated and pressed it on above inoculated Agar plate and removed immediately by making a well in the plate. Likewise, other four well were made on each plate. $75 \mu \mathrm{l}, 50 \mu \mathrm{l}, 25 \mu \mathrm{l}, 10 \mu \mathrm{l}$ and $5 \mu \mathrm{l}$ of MIE were added into the respective wells on each plate. Agar plates were incubated for $18-24 \mathrm{~h}$ at $37^{\circ} \mathrm{C}$ in the incubator. After incubation, plates were read and zone of inhibition was measured to nearest whole in millimeter by holding the measuring device (Isenberg, 1992).

\section{RESULTS}

\section{Analytical profile}

The oily fraction was extracted from dried coarse powder of mango tree bark in soxhlet apparatus using petroleum ether. Various analytical profile of extracted oil is mentioned in Table 1.

Table 1: Analytical Properties of MIE.

\begin{tabular}{cc}
\hline Analytical Properties & Values \\
\hline Colour & Pale yellow \\
Melting point & $55-58{ }^{\circ} \mathrm{C}$ \\
Boling point & $232-237^{\circ} \mathrm{C}$ \\
Refractive index & 1.535 \\
\hline
\end{tabular}

\section{Thin layer chromatography (TLC)}

Chromatographic techniques were adopted to identify purity of the oil. Wherein 5 spots were seen with $\mathrm{R}_{\mathrm{f}}$ values 0.12 , $0.16,0.23,0.35,0.67$. Results of TLC are shown in Figure 1.

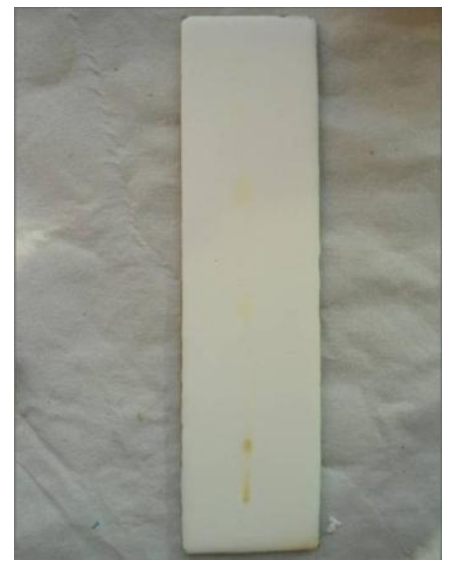

Fig 1: Thin Layer Chromatography of MIE. 


\section{Gas chromatography - mass spectroscopy (GCMS)}

GCMS study was undertaken to identify the individual components of the bark oil. Totally there were 13 different peaks observed in the chromatogram. The observed $\mathrm{R}_{\mathrm{t}}$ values are as follows, 4.734, 5.115, 5.539, 5.809, 6.609, 6.723, 6.850, 7.142, $7.241,7.524,7.726,7.808,8.016$. The main peak was observed at $R_{t}$ value 6.723 , this corresponds to the $26.92 \%$ composition of the oil.

Corresponding molecular weight $\mathrm{m} / \mathrm{z}$ values of the 13 peaks observed in GCMS are 85, 256, 99, 99, 300, 300, 300, 129, 141, 149, 256, 149, and 155 respectively. According to the literature values, following compounds which may be present are Procatechuic acid (154.12), Epicatechin (290.27), Oxyresveratrol (244.24) and n-Heneicosane (269.59), Palmatic acid (256.42).

Table 2: Spots and their $\mathrm{R}_{\mathrm{f}}$ values.

\begin{tabular}{lc}
\hline Spots & $\mathbf{R}_{\mathbf{f}}$ Value \\
\hline Spot 1 & 0.12 \\
Spot 2 & 0.16 \\
Spot 3 & 0.23 \\
Spot 4 & 0.35 \\
Spot 5 & 0.67 \\
\hline
\end{tabular}

\section{Minimum inhibitory concentration (MIC)}

The antimicrobial assay results showed that MIE exhibited in-vitro antibacterial activity against Gram-positive and Gram-negative bacteria. The MIC values are depicted in Table 4. MIE showed MIC value for E.coli, P. Aeruginosa and B.subtillis at $0.2 \mu \mathrm{g} / \mathrm{ml}$ respectively. Whereas, MIE showed MIC value for S.aureus at $0.8 \mu \mathrm{g} / \mathrm{ml}$, which was considered as Sensitive (S).

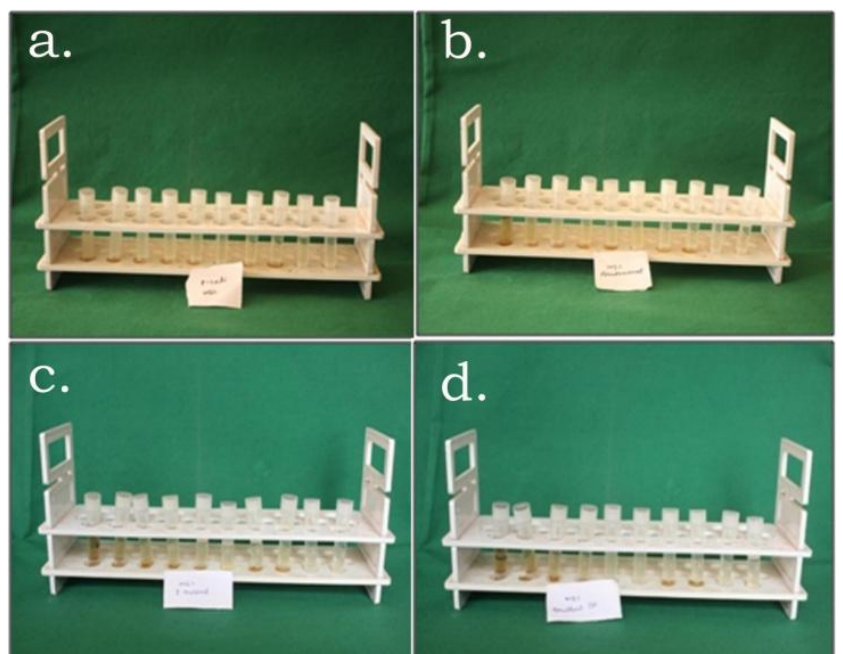

Fig 2: minimum inhibitory concentration (a- E.coli, b- P.aeruginosa, c-S.aureus, d- B.subtilis).

\section{Zone of inhibition}

The antimicrobial assay showed that MIE exhibited invitro antibacterial activity against Gram-positive and Gramnegative bacteria. The Concentration of MIE was $10 \mathrm{mg} / \mathrm{ml}$ which showed zone of inhibition of $13 \mathrm{~mm}$ and $10 \mathrm{~mm}$ at $50 \mu \mathrm{l}$ against $P$. Aeruginosa and E. coli respectively. Whereas zone of inhibition of
$8 \mathrm{~mm}$ for B. subtillis at $25 \mu \mathrm{l}$ and that of $8 \mathrm{~mm}$ for $S$. aureus at 75 $\mu 1$. The detailed results have been depicted in Table 3 .

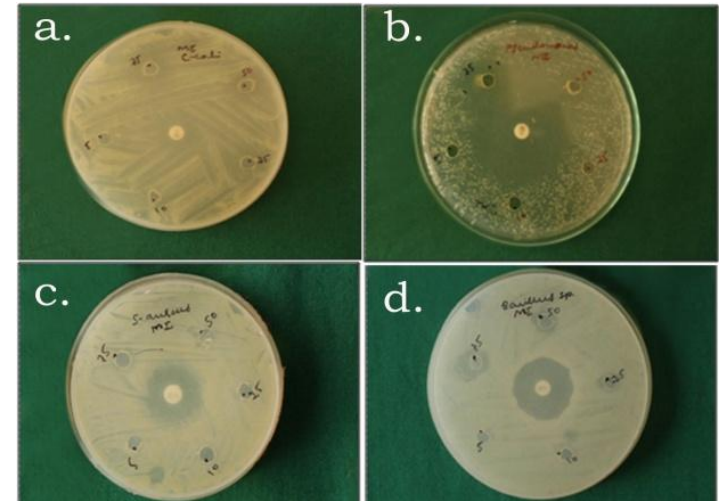

Fig. 3: Zone of inhibition (a- E.coli, b- P.aeruginosa, c- S.aureus, d- B.subtilis).

\section{DISCUSSION}

MIE was extracted from locally available mango tree bark which is pale yellow in colour, characteristic odour. Literature survey indicates that MIE has been used for throat infection in home remedies due to the astringent character (Chetan et al., 2014). MIE consists of various volatile oil, fatty acids, which has significant lipophilicity this may be useful for inhibition microbial growth.

In the present study, antimicrobial assays were performed by the agar-well diffusion and MIC method. The antimicrobial activity of the MIE is shown in Table 3 and 4 respectively. All the microbes used in the present study were sensitive to the MIE and showed a potential activity against growth of both gram positive and gram negative bacteria. The activity was concentration dependent against the various micro organisms; which are shown below.

B. subtilis, E. coli, P. Aeruginosa,> S. aureus.

Table 3: Agar well diffusion technique

\begin{tabular}{cccccccc} 
Test Bacteria & $\mathbf{7 5} \boldsymbol{\mu l}$ & $\mathbf{5 0} \boldsymbol{\mu l}$ & $\mathbf{2 5} \boldsymbol{\mu l}$ & $\mathbf{1 0} \boldsymbol{\mu l}$ & $\mathbf{5} \boldsymbol{\mu l}$ & \\
& & & & & & & \\
\hline P. Aeruginosa & $20 \mathrm{~mm}$ & $13 \mathrm{~mm}$ & $\mathrm{R}$ & $\mathrm{R}$ & $\mathrm{R}$ & $40 \mathrm{~mm}$ \\
E.Coli & $12 \mathrm{~mm}$ & $10 \mathrm{~mm}$ & $\mathrm{R}$ & $\mathrm{R}$ & $\mathrm{R}$ & $16 \mathrm{~mm}$ \\
B.subtillis & $15 \mathrm{~mm}$ & $10 \mathrm{~mm}$ & $8 \mathrm{~mm}$ & $\mathrm{R}$ & $\mathrm{R}$ & $28 \mathrm{~mm}$ \\
S.aureus & $8 \mathrm{~mm}$ & $\mathrm{R}$ & $\mathrm{R}$ & $\mathrm{R}$ & $\mathrm{R}$ & $20 \mathrm{~mm}$ \\
\hline
\end{tabular}

These bacteria are leading cause of both hospital and community acquired infections and has greater virulence capabilities as well as resistant development than other bacteria. This broad spectrum activity should make it useful for the treatment of infections requiring prompt therapy. Variation in activity among different extracting solvents and also amongst different bacterial strains has been reported. 
Table 4: Minimum inhibitory concentration (MIC).

\begin{tabular}{|c|c|c|c|c|c|c|c|}
\hline Test Bacteria & 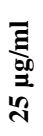 & 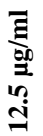 & 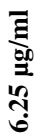 & 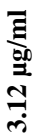 & 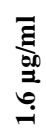 & 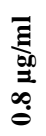 & 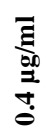 \\
\hline E.coli & $\mathrm{S}$ & $\mathrm{S}$ & $\mathrm{S}$ & $\mathrm{S}$ & $\mathrm{S}$ & $\mathrm{S}$ & $\mathrm{S}$ \\
\hline P.aeruginosa & $\mathrm{S}$ & $\mathrm{S}$ & $S$ & $\mathrm{~S}$ & $\mathrm{~S}$ & $\mathrm{~S}$ & $\mathrm{~S}$ \\
\hline S.aureus & $\mathrm{S}$ & $\mathrm{S}$ & $S$ & $\mathrm{~S}$ & $\mathrm{~S}$ & $\mathrm{~S}$ & $\mathrm{R}$ \\
\hline B.subtilis & $\mathrm{S}$ & $\mathrm{S}$ & $\mathrm{S}$ & $\mathrm{S}$ & $\mathrm{S}$ & $\mathrm{S}$ & $\mathrm{S}$ \\
\hline
\end{tabular}

S- Sensitive, R- Resistant

\section{CONCLUSION}

Findings of the present study reveal presences of different active constituents like palmatic acid, procatechuic acid in MIE. Extract also showed potential antibacterial activity against different Gram positive and Gram negative bacteria by performing MIC and zone of inhibition. These results are quite interesting and encouraging to researchers to carry out further studies for its clinical use.

Financial support and sponsorship: Nil.

Conflict of Interests: There are no conflicts of interest.

\section{REFERENCES}

Tim-cushnie TP, Lamb AJ. Antimicrobial activity of flavonoids. Int J Antimicrob Agents, 2005; 26:343-56.

Karaman I, Sahin F, Güllüce M, Ögütçü H, Sengul M, Adigüzel A. Antimicrobial activity of aqueous and methanol extracts of Juniperus oxycedrus L. J Ethnopharmacol, 2003; 85(2-3):1-5.

Abu Mustafa EA, Fayez MBE. Natural coumarins. Marmesin and marmesinin, further products from the fruits of Ammi majus. J Org Chem, 1961; 26:261-6.

Shah KA, Patel MB, Patel RJ, Parmar PK. Mangifera indica (Mango). Phcog Rev, 2010; 4(7):42-48.

Adeneye AA, Awodele O, Aiyeola SA, Benebo AS. Modulatory potentials of the aqueous stem bark extract of Mangifera indica on carbon tetrachloride-induced hepatotoxicity in rats. J Tradit Complement Med, 2015; 5(2):106-15.

Chetan S, Kulkarni AR, Mannasaheb BA, Gajare R. Immunomostimulant phytoconstituents from Mangifera indica $\mathrm{L}$. bark oil. J Phytopharmacol, 2014; 3(2):139-48.

Schwalve, Moore, Goodwin. 2007. Antimicrobial susceptibility testing protocols. Boca Raton, Fla, USA: CRC Press.

Isenberg HD. 1992. Clinical microbiology procedures handbook. Washington DC: American society for microbiology. ASM Press.

\section{How to cite this article:}

Savant CB, Kulkarni AR, Abdel-Wahab BA, Al-Qahtani AM, Mannasaheb BA, Shaikh IA. Phytochemical characterization and Antibacterial potentials of Mangifera indica L. bark oil. J App Pharm Sci, 2017; 7 (04): 138-141. 